\title{
Is There a Causal Relation between Trade Openness and Economic Growth in the WAEMU Countries?
}

\author{
Akilou Amadou ${ }^{1}$ \\ ${ }^{1}$ Faculté des Sciences Economiques et de Gestion, Université de Lomé, Togo \\ Correspondence: Akilou Amadou, Lecturer of Economics, Faculté des Sciences Economiques et de Gestion, \\ Université de Lomé, B. P. 1515, Togo. E-mail: akilouamadou@yahoo.fr
}

Received: April 4, 2013

Accepted: May 4, $2013 \quad$ Online Published: May 21, 2013

doi:10.5539/ijef.v5n6p151

URL: http://dx.doi.org/10.5539/ijef.v5n6p151

\begin{abstract}
In the West African Economic and Monetary Union (WAEMU) countries, it is a priori difficult to establish relationship between trade openness and economic growth. This is why we have tried to do so empirically using Granger causality test. The results indicate that apart from Côte d'Ivoire and at 10\% level trade openness doesn't cause economic growth in the WAEMU countries. Conversely, economic growth does not cause trade openness. These results can be explained essentially by the fact that all the conditions are not yet assembled in the WAEMU countries so that trade openness can interact with economic growth. Indeed, openness is usually more profitable to countries that record quite high growth rates and whose industries have already reached maturity or are closed to maturity. This is not the case of the WAEMU countries.
\end{abstract}

Keywords: causality, openness, growth, WAEMU countries

\section{Introduction}

The issue of causation between trade openness and economic growth remains always asked, as it is still not clear whether it is the increase in international trade that stimulates economic growth or the other way around. The implicit question relating to developing countries (DC) is whether the main sources of growth and industrialization are external, i.e. learning through trade (exports or imports) or internal, i.e. investment in physical and human capital and research and development (R \& D). On the one hand, if the sources of growth are external, these countries would need to further reduce trade barriers that restrict imports and exports externalities effects. On the other hand, if the sources of growth are internal, they may need to devote their scarce resources to investments in physical and human capital development. Therefore the main objective of this paper is to empirically determine the direction of causality between trade openness and economic growth in the WAEMU countries.

The remainder of the paper is structured as follows. Section 2 reviewed the literature on the relationship between trade openness and economic growth. Sections 3 and 4 are respectively devoted to the methodology and conclusion of the analysis.

\section{Review of the Literature}

Theoretical analyses and empirical studies indicate that there is an interaction between trade openness and economic growth.

\subsection{Theoretical Analysis}

According to theoretical analyses, the relationship between trade openness and economic growth can be either static or dynamic.

In a static context, if we consider a Heckscher-Ohlin model (H-O model) in which there is only one distortion due to a tariff on an imported good, prices of international goods being constant, a tariff reduction can lead to an increase of imports and exports, as well as GDP. The cause of the growth of output is therefore more trade openness. Output growth may also result from better exploitation of economies of scale, as exporting firms enjoy higher productivity than those that did not export (Krugman, 1981). On the other hand, if we consider an H-O model in which there are distortions such as downward real wage rigidity, greater openness which translates into a reduction in domestic prices for labor intensive goods can lead to unemployment and a reduction of GDP and welfare (Brecher, 1974; Bhagwati, 1994). It is also possible to analyze the effect of economic growth on trade and 
trade openness in the context of fixed price H-O model. According to the theorem of Rybczynski, an exogenous increase in the stock of capital, for instance, leads to an increase of the output of goods intensive in capital and a decrease of labor intensive ones. If the country concerned has relatively more capital than the rest of the world, the increase in capital stock leads to more exchanges. Conversely, if the country is abundantly endowed with labor, the increase in the capital stock causes a decrease in trade.

From a dynamic perspective, the new theories of economic growth initiated by Romer (1986, 1990), Lucas (1988), Aghion and Howitt (1992) and Grossman and Helpman (1991), allow linking trade openness and economic growth. Generally, the effect of the reduction of tariffs on economic growth depends on the effect of tariffs on the allocation of production factors to research and development (R\&D). If trade openness causes more allocation of resources to R\&D, it will result in more growth (Grossman and Helpman, 1991, 1995). In the contrary case, it reduces growth. Rivera-Batiz and Romer (1991) found that openness may have a positive impact on growth if it entails an increase of the stock of knowledge available in a country. If international externalities of knowledge are perfect, countries grow faster after openness. If knowledge externalities are imperfect and a developing country cannot use the knowledge available in industrialized countries, trade openness causes differences in the growth paths. The growth rate of a country which was rich at the time of trade openness will increase while the one of initially poor country will tend towards zero (Grossman and Helpman, 1991). Stokey (1991) and Tang and Walde (2000) also showed that international trade can lead to welfare losses and a reduction in the rate of growth.

Theoretically, it appears that trade openness can affect positively or not economic growth, and vice versa.

\subsection{Empirical Studies}

Many empirical studies are devoted to the analysis of the effect of trade openness on economic growth. While most of these studies are criticized on the ground that they use inadequate estimation methods or wrong indicators to measure openness (see Rodriguez and Rodrik, 1999), their findings are mixed. Some researchs such as Dollar (1992), Edwards (1992), Sachs and Warner (1995), Harrison (1996), Onafowora and Owoye (1998), Greenaway et al. (2002), Lee et al. (2004), Salinas and Aksoy (2006), Billmeier and Nannicini (2007), Estevadeordal and Taylor (2008) found that trade openness affects positively economic growth. Other analyses such as Taylor (1991), Rodriguez and Rodrik (1999), Brunner (2003), Shafaeddin (2005), Rodrik (2006), have an opposite point of view. Further work by Krueger (1998), Baldwin (2003), Winters (2004), Bolaky and Freund (2004), and Chang et al. (2005) established that in order to strongly stimulate economic growth, trade openness must -- among other policies -- be combined with investing in infrastructure and building strong and good quality institutions.

Another limit of these studies is that they essentially seek to establish a one-way relationship between trade openness and economic growth as opposed to a relation of causality or direction of influence. Jung and Marshall (1985) were among the first to investigate the relevance of results obtained with ordinary least squares (OLS) estimates to analyze a causal relationship between exports and economic growth in Southeast Asia during the 1950-1981 period. In fact, the dramatic increase in trade and exports in East Asia is often seen as the main source of the rapid industrialization and convergence of the economies in this region. The intervention policies implemented earlier by the Governments of these countries (through industrial and technological policies and human capital development) have contributed to improving their comparative advantage and enhancing the development of their economies prior to their openness to trade. The results show that causality between exports and economic growth is not obvious in all cases. In Indonesia, it appears that it is exports that cause growth while in Thailand it is growth that causes exports. In Korea, exports cause low growth. In Taiwan and Philippines, there is no causal relationship between exports and economic growth. Levine and Renelt (1992) and Bradford and Chawkin (1993) found similar results by adding investment to the existing corpus of variables in their analysis. The results suggest that the link between investment and economic growth was more significant than between exports and economic growth. Harrison (1996), after Granger causality tests, concluded that the direction of causality between openness and economic growth was not resolved. Rodrik (1995) studied four countries (Korea, Taiwan, Chile and Turkey) and presented the results of causality in the Granger sense between the share of investment in GDP and the share of exports and imports in GDP. He found that the links were ambiguous. In Korea, investment has caused openness while in Taiwan, there is a feedback. No relation of causality was detected for Chile and Turkey.

The above review of literature shows that the relationship between trade openness and economic growth can take many forms. Further empirical studies may be needed to determine the type of relationships which are the most relevant.

\section{Methodology}

To determine the causal relationship between trade openness and economic growth in WAEMU countries, we use 
the Granger causality test (1969) in the framework of an autoregressive model.

\subsection{The Granger Causality Test}

The Granger causality test requires the estimation of the two following regressions:

$$
\begin{gathered}
y_{t}=\phi_{0}+\sum_{i=1}^{n} \alpha_{i} O u v_{t-i}+\sum_{j=1}^{n} \beta_{j} y_{t-j}+\mu_{1 t} \\
O u v_{t}=\varphi_{0}+\sum_{i=1}^{n} \lambda_{i} O u v_{t-i}+\sum_{j=1}^{n} \delta_{j} y_{t-j}+\mu_{2 t}
\end{gathered}
$$

Where $y$ and $O u v$ are respectively economic growth and trade openness. The rate of economic growth is measured by the rate of growth of real GDP per capita. Due to the criticism against existing indicators of trade openness (see Rodriguez and Rodrik, 1999), and owing to data availability, we used the share of exports and imports in GDP as an indicator of the trade openness. $\mu_{1 t}$ and $\mu_{2 t}$ are terms of error supposed to be uncorrelated.

The following steps are implemented when the Granger causality test is run:

1 - The regression of $y$ on its own lagged values (constrained regression). From this regression, we get the constrained sum of squared residue $\left(\mathrm{SCR}_{\mathrm{C}}\right)$.

2 - The regression of $y$ on its own lagged values and those of openness (non-constrained regression). From this regression, we get the unconstrained sum of squared residue $\left(\mathrm{SCR}_{\mathrm{NC}}\right)$.

3 - The null hypothesis is tested $\left(\mathrm{H}_{0}=\Sigma \alpha \mathrm{i}=0\right)$ by applying the test of Fisher (F) given by:

$$
F=\frac{\left(S C R_{C}-S C R_{N C}\right) / m}{S C R_{N C} /(n-k-1)}
$$

which follows an $F$ distribution with $\mathrm{m}$ and (n-k-1) degrees of freedom. $m$ is the number of lagged $O u v$ terms and $k$ is the number of parameters estimated in the unconstrained regression (without intercept).

4 - If the calculated $F$ value is greater than the critical $F$ value at the selected significance level, the null hypothesis is rejected.

5- All these steps are repeated to determine whether or not y causes Ouv.

Four cases may arise:

- one-way causality from $O u v$ to $y$ if $\Sigma \alpha_{\mathrm{i}} \neq 0$ and $\Sigma \delta_{\mathrm{j}}=0$,

- one-way causality of $y$ to $O u v$ if $\Sigma \alpha_{\mathrm{i}}=0$ and if $\Sigma \delta_{\mathrm{j}} \neq 0$,

- a bilateral causality or feedback if $\Sigma \alpha_{\mathrm{i}} \neq 0$ and if $\Sigma \delta_{\mathrm{j}} \neq 0$,

- independence between $y$ and $O u v$ if $\Sigma \alpha_{\mathrm{i}}=0$ and $\Sigma \delta_{\mathrm{j}}=0$.

\subsection{Results}

The Granger causality test is valid if variables are stationary and if they are not cointegrated. This is why unit root and cointegration tests must first be run before undertaking the test.

The Augmented Dickey-Fuller test of unit root (ADF) is used to study the stationarity of the series of $y$ and $O u v$. Results (see table A1 of appendix) indicate that at 5\% level variables $y$ and $O u v$ are stationary for all the countries of our sample.

The test of Johansen is used for cointegration. It appears that there is no cointegration relationship between the two variables (see table A2 in the appendix).

The results of Granger test are also sensitive to the number of lags introduced in the model. Since this test is based on the same principle as the vector autoregressive models (VAR models), unrestrictive VAR are estimated for lags of 1 to 5. Akaike and Schwarz information criteria are used to determine the optimal number of lags. However, it appears that for some countries (Benin, Burkina Faso, Côte d'Ivoire and Togo), the number of optimal lag is not the same from one criterion to another (see table A3 in the appendix). This is why the Granger test is conducted for optimal lags obtained with the two criteria. The values of the Fisher statistics are summarized in table 1 below.

According to these results, at $5 \%$ significance level, the calculated Fisher statistics are less than the tabulated statistics. This means that there is no causal relationship between trade openness and economic growth. In other words, there is independence between trade openness and economic growth in each of the WAEMU countries. However, at $10 \%$ significance level and with a lag of 4 periods, it appears that trade openness Granger cause 
economic growth in Côte d'Ivoire as the calculated Fisher statistic is greater than its tabulated value.

Table 1. Relationship between trade openness and economic growth (Fisher statistics values)

\begin{tabular}{lllllll}
\hline \multirow{2}{*}{$\begin{array}{l}\text { Country } \\
\text { Lags }\end{array}$} & \multicolumn{5}{c}{ Openness to growth } & \multicolumn{5}{c}{ Growth to openness } \\
\cline { 2 - 7 } & 1 & 3 & 4 & 1 & 3 & 4 \\
\hline Benin & 0,491 & - & 1,399 & 0,119 & - & 1,363 \\
Burkina Faso & 2,063 & 1,071 & - & 0,082 & 0,966 & - \\
Côte d'Ivoire & 0,557 & - & $2,273^{*}$ & 0,093 & - & 0,786 \\
Mali & 1,562 & - & - & 1,434 & - & - \\
Niger & 1,162 & - & - & 0,018 & - & - \\
Senegal & 0,138 & - & - & 0,991 & - & - \\
Togo & 0,036 & - & 0,582 & 0,419 & - & 0,327 \\
\hline
\end{tabular}

Note: * Significance at $10 \%$ level.

To see if there's a causal relationship between trade openness and economic growth in the WAEMU countries taken as a whole, we have built a panel dataset on the period 1962-2005. To avoid duplication that the automatic generation of lagged variables can cause, we have rearranged the panel data prior to running the test of causality. This rearrangement caused a reduction in the length of the series (due to the loss of observations) in line with to the number of lags introduced in the models. This has resulted in changes in periods and number of observations. The new periods and the corresponding numbers of observations are as follows:

- for a lag of one period: 295 observation on the period 1963-2005

- for a lag of two periods: 288 observations on the period 1964-2005

- for a lag of three periods: 281 observations on the period 1965-2005

- for a lag of four periods: 274 observations on the period 1966-2005

- for a lag of five periods: 267 observations on the period 1967-2005

As previously, before running the Granger causality test, we first conducted tests of stationarity and cointegration on the variables $y$ and openness. These tests revealed that the variables are stationary and are not cointegrated (see tables A4 and A5 in appendix). Akaike and Schwarz information criteria are also applied to determine the number of optimal lags, but as previously, they give different results. This is why the causation test has been conducted on lags of 1 to 5 . The results are contained in table 2 below.

Table 2. Causality relationship between trade openness and economic growth (values of Fisher's statistics)

\begin{tabular}{llllll}
\hline Direction of causality & \multicolumn{1}{l}{ Lags } & & & \\
\cline { 2 - 6 } & $\mathbf{1}$ & $\mathbf{2}$ & $\mathbf{3}$ & $\mathbf{4}$ & $\mathbf{5}$ \\
\cline { 2 - 6 } Openness to growth & 2,18 & 2,50 & 2,57 & 1,88 & 1,60 \\
Growth to openness & 0,32 & 0,18 & 2,20 & 1,73 & 1,51 \\
\hline
\end{tabular}

At $5 \%$ significance level, the calculated Fisher statistics are lower than their tabulated values. These results also suggest that there is independence or no causal relationship between trade openness and economic growth in the WAEMU countries.

These results are consistent with the results obtained by some authors, in occurrence Jung and Marshall (1985) and Rodrik (1995). They can be explained essentially by the fact that all the conditions are yet to be met in the WAEMU countries for trade openness to improve economic growth. Trade openness is usually more favorable to growth in countries with high initial growth rates and with relatively developed industrial base. WAEMU countries export mainly primary products, which prices are essentially determined on the international markets and depend more on demand and supply factors (including natural factors) than on trade policies implemented by these countries. Also, international prices are unstable and sometimes tend to fall, thereby promoting instability and reduction of export earnings, which may be detrimental to fiscal sustainability and economic growth. Finally, to be favorable to economic growth, trade openness must - among other policies -- be accompanied by investments in infrastructure and human capital, as well as the establishment of good quality institutions in order to improve governance and the business climate, all of which are conducive to economic growth. 


\section{Conclusion}

Historically, the causality between trade openness and economic growth seems to be bi-directional. Typically, in times of crisis, countries tend to restrict their openness to the rest of the world by increasing their levels of protection and open their economies in period of relatively high growth. This is the case in the U.S. where the calls for protectionism re-emerge whenever growth rates decrease and imports increase. South East Asian countries such as South Korea, Singapore and Taiwan experienced high growth rates by implementing import substitution policies at first before opening up to trade.

The results obtained by analyzing the causal relationship between openness and economic growth in the WAEMU countries suggest that it's only in Côte d'Ivoire and at $10 \%$ level that trade openness cause's economic growth. Therefore, it would be more profitable this country to open its economy, because external factors can carry its economic growth. For other WAEMU countries, trade openness does not cause economic growth. Conversely, economic growth does not cause trade openness. In other words, there's independence between trade openness and economic growth in these countries.

\section{References}

Billmeier, A., \& Nannicini, T. (2007). Trade openness and growth: pursuing empirical glasnost. IMF Working Paper, WP/07/156.

Bradford, C., \& Chakwin, N. (1993). Alternative explanations of the trade-output correlation in the East Asian Economies. OECD Development Centre Technical Paper, No. 87. http://dx.doi.org/10.1787/448367214462

Brecher, R. (1974). Minimum wage rates and the pure theory of international trade. Quarterly Journal of Economics, 88, 98-116. http://dx.doi.org/10.2307/1881796

Brunner, A. D. (2003). The long-run effects of trade on income and income growth. IMF Working Paper, $\mathrm{WP} / 03 / 37$.

Estevadeordal, A., \& Taylor, A. M. (2008). Is Washington consensus dead? Growth, openness, and the great liberalization, 1970s-2000s. NBER Working Paper, 14264.

Granger, C. (1969). Investigating causal relations by econometric models and cross-spectral methods. Econometrica, 37, 424-438. http://dx.doi.org/10.2307/1912791

Grossman, G. M., \& Helpman, E. (1991). Innovation and growth in the global economy. Cambridge, MA: MIT Press.

Grossman, G. M., \& Helpman, E. (1995). Technology and trade. In Grossman, G. M. \& Rogoff, K. (Eds.), Handbook of International Economics (Vol. III). Amsterdam: Elsevier.

Harrison, A. (1996). Openness and growth: a time-series, cross-country analysis for developing countries. Journal of Development Economics, 48, 419-447. http://dx.doi.org/10.1016/0304-3878(95)00042-9

Jung, S. W., \& Marshall, P. J. (1985). Exports, growth and causality in developing countries. Journal of Development Economics, 18, 1-12. http://dx.doi.org/10.1016/0304-3878(85)90002-1

Krugman, P. (1981). Intraindustry specialization and the gains from trade. Journal of Political Economy, 89, 959-973. http://dx.doi.org/10.1086/261015

Lee, H. Y., Antonio, R. L., \& Rigobon, R. (2004). Once again, is openness good for growth? Journal of Development Economics, 75(2), 451-472. http://dx.doi.org/10.1016/j.jdeveco.2004.06.006

Levine, R., \& Renelt, D. (1992). A sensitivity analysis of cross-country growth regressions. American Economic Review, 82, 942-963.

Rivera-Batiz, L. A., \& Romer, P. M. (1991). Economic integration and endogenous growth. The Quarterly Journal of Economics, 106, 531-555. http://dx.doi.org/10.2307/2937946

Rodrik, D. (1995). Trade strategy, investment and exports: another look at East Asia. NBER Working Paper, 5399.

Rodrik, D. (2006). Goodbye Washington consensus, hello Washington confusion? A review of the World Bank's economic growth in the 1990s: learning of the decade reform. Journal of Economic Literature, XLIV, 973-987. http://dx.doi.org/10.1257/jel.44.4.973

Romer, P. M. (1986). Increasing returns and long-run growth. Journal of Political Economy, 94, 1002-1037. http://dx.doi.org/10.1086/261420 
Romer, P. M. (1990). Endogenous technological change. Journal of Political Economy, 98, S71-S102. http://dx.doi.org/10.1086/261725

Salinas, G., \& Aksoy, A. (2006). Growth before and after trade liberalization. World Bank Policy Research Working Paper, 4062.

Shafaeddin, S. M. (2005). Trade liberalization and economic reform in developing countries: structural change or de-industrialization. Discussion papers, UNCTAD, Geneva.

Stokey, N. (1991). Human capital, product quality and growth. Quarterly Journal of Economics, 106, 587-661. http://dx.doi.org/10.2307/2937948

Tang, P. J. G., \& Wälde, K. (2000). International competition, growth and welfare. European Economic Review, 45, 1439-1459. http://dx.doi.org/10.1016/S0014-2921(00)00069-6

\section{Appendix}

Table A1. Results of unit root tests ${ }^{1}$

\begin{tabular}{lllll}
\hline Countries & \multicolumn{2}{l}{ Variables } & Ouv & \\
\cline { 2 - 5 } & ADF values & Critical value* & ADF values & Critical value* \\
\hline Benin & $-5,28$ & $-2,93$ & $-4,35$ & $-2,93$ \\
Burkina Faso & $-5,31$ & $-2,93$ & $-5,05$ & $-2,93$ \\
Côte d'Ivoire & $-3,29$ & $-2,93$ & $-4,91$ & $-2,93$ \\
Mali & $-4,48$ & $-2,94$ & $-6,86$ & $-2,94$ \\
Niger & $-5,33$ & $-2,93$ & $-4,79$ & $-2,93$ \\
Senegal & $-5,09$ & $-2,93$ & $-5,00$ & $-2,93$ \\
Togo & $-3,95$ & $-2,93$ & $-5,84$ & $-2,93$ \\
\hline
\end{tabular}

Notes: * signification at $5 \% .{ }^{1}$ Only results obtained at $5 \%$ have been reported.

Table A2. Results of cointegration tests

\begin{tabular}{lll}
\hline Countries & Likelihood ratio (LR) & Critical value at 5\% \\
\hline Benin & 38,14 & 15,41 \\
Burkina Faso & 43,51 & 15,41 \\
Côte d'Ivoire & 32,56 & 15,41 \\
Mali & 43,67 & 15,41 \\
Niger & 41,48 & 15,41 \\
Senegal & 43,73 & 15,41 \\
Togo & 43,53 & 15,41 \\
\hline
\end{tabular}

Table A3. Number of optimal lags

\begin{tabular}{llllllll}
\hline Criteria & Benin & Burkina Faso & Côte d'Ivoire & Mali & Niger & Senegal & Togo \\
\hline Akaike & 1 & 1 & 4 & 1 & 1 & 1 & 4 \\
Schwarz & 4 & 3 & 1 & 1 & 1 & 1 & 1 \\
\hline
\end{tabular}

Table A4. Results of unit root tests (panel)

\begin{tabular}{lll}
\hline Variables & ADF statistics & Critical values at $5 \%$ \\
\hline Y & $-11,06$ & $-2,87$ \\
Ouv & $-14,66$ & $-2,87$ \\
\hline
\end{tabular}

Table A5. Results of cointegration tests (panel)

\begin{tabular}{lll}
\hline Hypothesis & Likelihood Ratio (LR) & Critical Value at 5\% \\
\hline None cointegration relation & 267,98 & 15,41 \\
At least one cointegration relation & 100,39 & 3,76 \\
\hline
\end{tabular}

